\title{
Międzynarodowa konferencja naukowa „Godność - od prawa rzymskiego do Karty z Nicei” Taranto - Monopoli 13-15 maja 2009 r.
}

W dniach 13-15 maja 2009 r. odbyła się we włoskich miejscowościach Taranto i Monopoli Międzynarodowa konferencja naukowa pod tytułem: „Dignitas - dal Diritto Romano alla Carta di Nizza" (Godność - od prawa rzymskiego do Karty z Nicei). Konferencja, będąca jednym z efektów zapoczątkowanej w 2004 r. współpracy między pracownikami naukowymi Wydziału Prawa Uniwersytetu w Białymstoku i środowiskiem prawniczym Uniwersytetu w Bari, zorganizowana została przez zamiejscowy Wydział Prawa włoskiego uniwersytetu z siedzibą w Taranto we współpracy z Centro Interdipartimentale di Studi di Diritti e Culture Pre-latine, Latine ed Orientali (Cediclo).

Tematyka konferencji spotkała się z dużym zainteresowaniem przedstawicieli wielu środowisk naukowych. W murach tarenckiego wydziału zebrali się prawnicy, historycy, filozofowie, etycy, a także członkowie włoskich i polskich korporacji prawniczych. Uroczystego otwarcia obrad dokonał A. F. Uricchio, dziekan Wydziału Prawa w Taranto i dyrektor Cediclo. Zgromadzonych na sali gości przywitali kolejno: A. Morelli (Prezes Sądu w Taranto), A. Esposito (dziekan Rady Adwokackiej w Taranto) i V. Di Maggio (Fundacja Scuola Forense w Taranto). Po krótkim wprowadzeniu przez twórców włosko-polskiego porozumienia o współpracy na polu naukowym - S. Tafaro i F. Lempę, głos zabrali prelegenci. Podczas pierwszej sesji, której przewodniczył F. Fistetti, wygłoszone zostały następujące referaty: M. L. De Filippi, La dignitas nellesperienza del diritto romano; F. Lempa, Poszanowanie godności człowieka $w$ środowisku pracy; K. Szczygielski, Ochrona godności osobistej niewolników w prawie rzymskim; S. P. Kursa, Niegodność dziedziczenia w polskim prawie spadkowym. Przebiegiem drugiej sesji kierował F. Lempa, a wystąpienia uczestników dotyczyły następujących zagadnień: F. Fistetti, Dignità e riconoscimento; A. Suławko-Karetko, Poszanowanie godności obywatela polskiego poza granicami Rzeczypospolitej Polskiej; F. A. Murillo, Dignidad y fiscalidad; F. Parente, La „clausola di dignità": una categoria giuridica a tutela della vita.

W trakcie jednodniowej przerwy organizatorzy konferencji zadbali, by uczestnicy mogli odwiedzić interesujące miejsca związane $\mathrm{z}$ historią i kulturą włoskiego regionu Apulia, w którego granicach toczyły się obrady. Zostały one wznowione 15 maja w miejscowości Monopoli. Pierwszy panel dyskusyjny, pod przewodnictwem A. Mandro, rozpoczął się od wystąpienia S. Tafaro: T. Muolo: una vita per la dignità dell'uomo. Kolejne referaty poświęcone zosta- 
ły następującym zagadnieniom: F. Mastroberti, Dignità: profili storici; T. Mróz, U. Drozdowska, Ochrona nasciturusa w polskim prawie cywilnym; M. Zdanowicz, Prawo do obywatelstwa w zjednoczonej Europie. Wybrane aspekty; C. Scattone, Dignità: diritto islamico; J. Matys, Ochrona godności w polskim kodeksie cywilnym; M. Mazzeo, Educazione familiare e dignitas romana nei rapporti con i figli e i minori; E. Kowalewska-Borys, Godność osoby ludzkiej w aspekcie karno-procesowym; M. Indellicato, Dignità ed etica; D. Gajowska-Serafin, Mobbing w świetle polskiego prawa pracy. W drugiej części obrad, nad której tokiem czuwała M. Zdanowicz, referenci podjęli się takich tematów, jak: L. Tafaro, Dignità umana e neuroscienze; D. Di Memmo, Dignità fra i coniugi fra eredità romana e testimonianze cristiane; A. Breczko, Problemy graniczne życia ludzkiego w kontekście godności człowieka; P. Niczyporuk, Ochrona prywatnoprawna nasciturusa w prawie rzymskim; M. Angiuli, Dignità e tassazione; F. Beer, Dalla dignitas romana alla dignitas della Carta di Nizza; E. Guzik-Makaruk, Handel organami ludzkimi; E. Cianciola, Dignità: categoria per il futuro.

Warto zaznaczyć, że wystąpienia prelegentów, tłumaczone na języki włoski i polski, były przedmiotem ożywionej dyskusji prowadzonej po każdej sesji. Podsumowując konferencję S. Tafaro podkreślił, że wszystkie referaty odznaczały się wysokim poziomem merytorycznym i dotyczyły wielu aspektów związanych $\mathrm{z}$ godnością osoby ludzkiej. Analizie poddane zostały regulacje różnych porządków prawnych, począwszy od ustawodawstwa starożytnego Rzymu, kończąc na zapisach proklamowanej 7 grudnia 2000 r. w Nicei Karty Praw Podstawowych Unii Europejskiej. Dzięki tak zakreślonej tematyce spotkania jego uczestnicy mieli okazję poznać szeroki przekrój poglądów na temat godności osoby ludzkiej. 